\title{
Control of biogenic amines in fermented sausages: role of starter cultures
}

\section{M.L. Latorre-Moratalla ${ }^{1}$, Sara Bover-Cid ${ }^{2}{ }^{*}$, M.T. Veciana-Nogués ${ }^{1}$ and M.C. Vidal-Carou ${ }^{1}$}

${ }^{1}$ Department of Nutrition and Food Science, Faculty of Pharmacy, University of Barcelona, Barcelona, Spain

2 IRTA-Food Safety Programme, Institute for Food and Agricultural Research and Technology, Monells, Spain

\section{Edited by:}

Giovanna Suzzi, Università degli Studi

di Teramo, Italy

Reviewed by:

Javier Carballo, University of Vigo,

Spain

Rosanna Tofalo, University of Teramo,

Italy

${ }^{*}$ Correspondence:

Sara Bover-Cid, IRTA-Food Safety

Programme, Institute for Food and

Agricultural Research and Technology,

Finca Camps i Armet s/n, E-17121

Monells, Spain.

e-mail: sara.bovercid@irta.cat
Biogenic amines show biological activity and exert undesirable physiological effects when absorbed at high concentrations. Biogenic amines are mainly formed by microbial decarboxylation of amino acids and thus are usually present in a wide range of foods, fermented sausages being one of the major biogenic amine sources. The use of selected starter cultures is one of the best technological measures to control aminogenesis during meat fermentation. Although with variable effectiveness, several works show the ability of some starters to render biogenic amine-free sausages. In this paper, the effect of different starter culture is reviewed and the factors determining their performance discussed.

Keywords: starter cultures, biogenic amines, amino acid decarboxylase, fermented sausages, amino oxidase, autochthonous

\section{INTRODUCTION}

Biologically active amines are nitrogenous low-molecular-weight substances with biological functions in animals, plants, and microorganisms. The biologically active amines known as biogenic amines include tyramine, histamine, phenylethylamine, tryptamine, putrescine, and cadaverine. They are mainly derived from the bacterial decarboxylation of precursor amino acids and can be found in nearly all types of foods in a wide and variable range of concentrations (Halász et al., 1994; Vidal-Carou et al., 2007).

Histamine, tyramine, and to lesser extent phenylethylamine are the main dietary biogenic amines associated with certain health disruptions, mainly involving vasoactive and psychoactive reactions: histaminic intoxication, food intolerance due to enteral histaminosis, food-induced migraines, and interaction between tyramine and MAOI drugs (Mariné-Font et al., 1995; Spano et al., 2010; Linares et al., 2011). Additionally, high contents of biogenic amines in foods have traditionally been used as an index of undesired microbial activity as a result of hygienically defective manufacturing or storage practices (Mariné-Font et al., 1995; Suzzi and Gardini, 2003; Ruiz-Capillas and Jiménez-Colmenero, 2004). However, the manufacture of fermented foods involve the activity of a variety of microorganisms, not only associated with the desired technological fermentative properties but also undesired contaminants. Both types of microbial activities entail noticeable risk of biogenic amine production. In this respect, the control of biogenic amine accumulation in fermented products is one of the present challenges of the food industry (Vidal-Carou et al., 2007). In this review, the influence of starter cultures as a technological measure to control aminogenesis during meat fermentation is reviewed and the factors determining their performance discussed.

\section{BIOGENIC AMINE CONTENTS IN FERMENTED SAUSAGES}

Fermented meat sausages, together with other fermented foods or beverages, constitute one of the food products that can accumulate higher biogenic amine contents (Suzzi and Gardini, 2003; Spano et al., 2010; EFSA Panel on Biological Hazards (BIOHAZ), 2011). Table 1 summarizes the occurrence of biogenic amines in retail fermented meat products of different countries. Tyramine is usually the most frequent and abundant biogenic amine found in fermented sausages. In terms of average values, it has been reported that fermented sausages show the highest tyramine content among fermented products (EFSA Panel on Biological Hazards (BIOHAZ), 2011). In fermented sausages, tyramine is produced by fermentative microbial population, mainly lactic acid bacteria (LAB, including lactobacilli and enterococci) and more rarely coagulase negative staphylococci (CNS; Straub et al., 1994; Masson et al., 1996; Montel et al., 1999; Bover-Cid et al., 2001a; Aymerich et al., 2006; Martín et al., 2006; Latorre-Moratalla et al., 2010a; Talon and Leroy, 2011). Latorre-Moratalla et al. (2010a) reported that $48 \%$ of $\mathrm{LAB}$ and $13 \%$ of staphylococci isolated from spontaneously fermented sausage are able to decarboxylate one or more amino acids.

The occurrence of putrescine and cadaverine is also quite common but more variable than tyramine. Although the contents of diamines in fermented sausages are relatively low, in a few cases their levels are extremely high, exceeding those of tyramine. The production of diamines is usually attributed to contaminant Gram-negative bacteria, such as enterobacteria and pseudomonas (Bover-Cid et al., 2001a; Durlu-Özkaya et al., 2001; Suzzi and Gardini, 2003). However, a number of publications show several LAB and CNS strains with a powerful capability of producing putrescine and/or cadaverine (Straub et al., 1995; Bover-Cid et al., 2001a; Martín et al., 2006; Latorre-Moratalla et al., 2010a). 


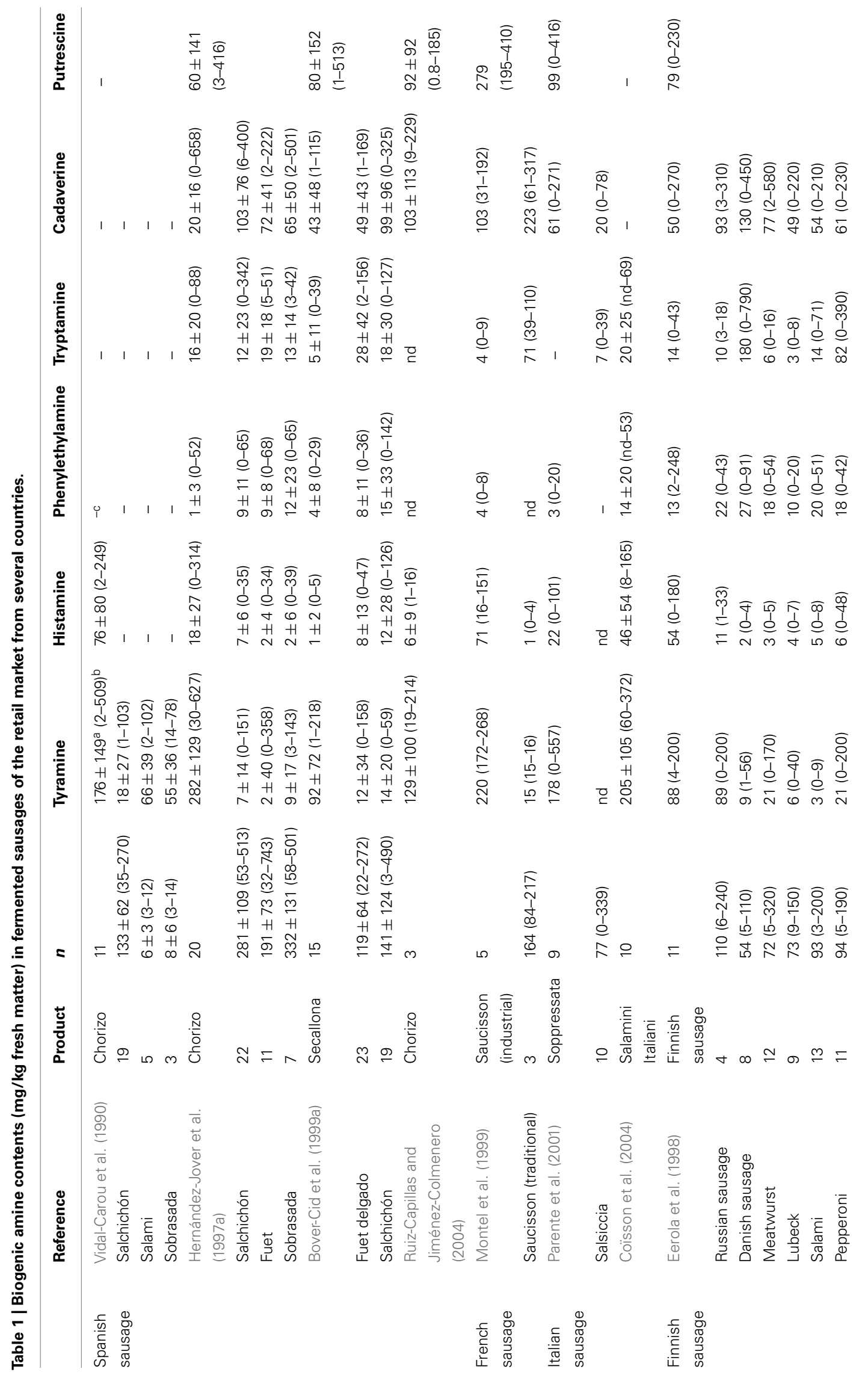




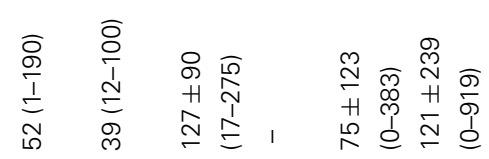

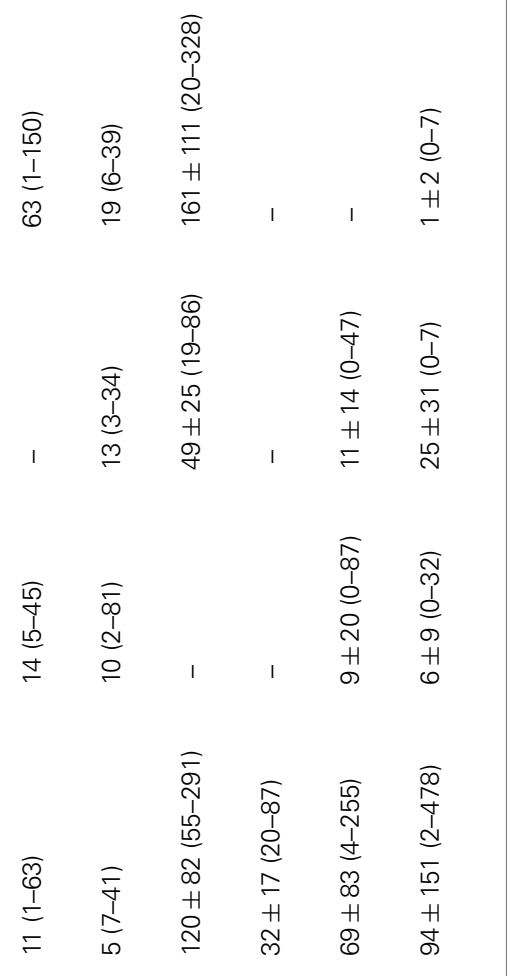

Therefore, fermentative activities can also result in a considerable diamine accumulation.

In contrast, histamine is usually more scarcely found in fermented sausages. However, in some particular samples it may reach quite high levels, usually accompanied by high amounts of other biogenic amines. Histamine production seems to be delimited to some strains of a reduced number of isolates of enterobacteria or LAB, which are not commonly found unless specific contaminations occur (Maijala and Eerola, 1993; Roig-Sagués et al., 1996; Silla-Santos, 1998; Bover-Cid et al., 2001a).

Phenylethylamine and tryptamine could be considered minor amines occurring in fermented sausages. Their accumulation seems dependent on the occurrence of high contents of tyramine associated with some LAB or CNS (Vidal-Carou et al., 2007).

Levels of biogenic amines in fermented sausages show a great variation among different types of products, manufacturers and products from the same manufacturer. The influence of the microbiological quality of raw materials, which varies in each production batch, is a key parameter to explain this variability. Additionally, other factors such as ingredients and additives (sugar, curing agents, spices, etc), diameter of sausage and technological ripening conditions (temperature and relative humidity) can also influence the phenomena associated with aminogenesis, including microbial growth, acidification, proteolysis, and activity of decarboxylases (Maijala et al., 1995; Bover-Cid et al., 1999a, 2001b; Parente et al., 2001; González-Fernández et al., 2003; Bozkurt and Erkmen, 2004; Komprda et al., 2004; Latorre-Moratalla et al., 2012).

\section{STARTER CULTURES FOR AMINOGENESIS CONTROL IN FERMENTED SAUSAGE TECHNOLOGICAL ROLE OF STARTER CULTURES IN RELATION TO AMINOGENESIS}

The hygienic quality of meat raw materials and ingredients is crucial to minimize the occurrence of microbial contaminants, and it thus constitutes a key point in controlling aminogenesis in fermented meat products (Maijala et al., 1995; Bover-Cid et al., 2000a,b; Naila et al., 2010). However, hygiene is a necessary, though not sufficient condition and additional technological measures focused on the control of aminogenic activity of endogenous microbiota are usually needed. Among the possible technological strategies, the use of starter cultures is one of the most important factors quantitatively affecting the accumulation of biogenic amines during sausage fermentation (Bover-Cid et al., 2000c; Suzzi and Gardini, 2003; Naila et al., 2010; EFSA Panel on Biological Hazards (BIOHAZ), 2011; Talon and Leroy, 2011). Indeed, the mechanism of starter cultures is based on preventing the outgrowth of the potential aminogenic endogenous bacteria together with their own inability to produce biogenic amines (Lonvaud-Funel, 2001; Suzzi and Gardini, 2003).

Strains of LAB and CNS specifically selected as starter cultures have to comply with some technological criteria, among which the adaptation to meat fermentation, the ability to compete with the natural (endogenous) microbiota of raw materials and the lack of amino acid decarboxylase capability are the most relevant for the control of biogenic amine production (Buckenhüskes, 1993; EFSA Panel on Biological Hazards (BIOHAZ), 2011; Talon and Leroy, 2011). Some LAB and CNS species usually 
used as meat starters (i.e., L. curvatus and S. carnosus) have been reported as strong biogenic amine producers, mainly of tyramine (Latorre-Moratalla et al., 2010a; Talon and Leroy, 2011). In contrast, species such as L. sakei, L. plantarum, and S. xylosus are usually described as weak or non-aminogenic microorganisms (Bover-Cid et al., 2001a; Aymerich et al., 2006; Latorre-Moratalla et al., 2010a; Linares et al., 2011). However, though some genera or species are more frequently reported than others to be able to produce specific biogenic amines, the ability to decarboxylate amino acids is a strain-dependent property (Bover-Cid and Holzapfel, 1999; Lonvaud-Funel, 2001; Linares et al., 2011). Therefore, it is necessary to carry out a case-by-case evaluation of the aminogenic activity of the strains to be selected as amine negative starter culture. For this purpose, several procedures have been reported (Marcobal et al., 2006; Landete et al., 2007; EFSA Panel on Biological Hazards (BIOHAZ), 2011). Amino acid decarboxylase potential might be tested by molecular techniques detecting specific genes coding for amino-acid decarboxylase. Nevertheless, the aminogenic potential of a given strain should be confirmed through the study of the phenotypic expression of this activity, both in vitro (as a screening procedure) and finally in real fermentation and ripening conditions (EFSA Panel on Biological Hazards (BIOHAZ), 2011).

\section{EFFECTIVENESS OF AMINE-NEGATIVE DECARBOXYLASE STARTER CULTURES IN BIOGENIC AMINE REDUCTION}

Several studies have evaluated the use of commercial and experimental starter cultures in order to reduce aminogenesis during the fermentation of sausages. Although a number of studies have demonstrated the beneficial effect of starter cultures in reducing biogenic amine accumulation (Maijala et al., 1995; HernándezJover et al., 1997b; Bover-Cid et al., 1999b; González-Fernández et al., 2003; Gençcelep et al., 2007; Gücükoglu and Küplülü, 2010; Lu et al., 2010; Baka et al., 2011), other studies failed to demonstrate the efficiency of starter cultures to reduce the presence of biogenic amines in some fermented meat products (Rice and Koehler, 1976; Buncic et al., 1993; Bauer et al., 1994; Paulsen and Bauer, 1997; Roig-Sagués et al., 1997; Parente et al., 2001; Bozkurt and Erkmen, 2002).

Table 2 summarizes the relative reduction of biogenic amines by the use of negative amine producer starter cultures obtained from different experiments. In these studies, different percentages of biogenic amine reduction are observed depending on the bacterial species inoculated, varying from $9 \%$ to practically $100 \%$. Moreover, some starters showed an ability to reduce the production of all amines and in other cases only reduce certain amines (Ayhan et al., 1999; Bover-Cid et al., 1999b; Gençcelep et al., 2007; Coloretti et al., 2008; Baka et al., 2011; Casquete et al., 2011).

In general, starters containing LAB species showed a higher effectiveness in biogenic amine reduction than starters including only CNS (Bover-Cid et al., 1999b, 2001b). LAB starter cultures could exert a more efficient replacement of endogenous microbiota with potential aminogenic ability, usually consisting of lactobacilli and enterococci. In particular within starters including LAB species, those containing L. sakei or L. plantarum are reported to significantly inhibit amine accumulation, though with different intensity depending on the strain and product
(Hernández-Jover et al., 1997b; Coloretti et al., 2008; LatorreMoratalla et al., 2010b; Baka et al., 2011; Tosukhowong et al., 2011). Within CNS, although their proteolytic activity could stimulate the aminogenesis by means of providing the amino acid precursors, Bover-Cid et al. (1999b) showed the potential of proteolytic staphylococci to inhibit biogenic amine production.

Several studies support a greater efficiency in biogenic amine reduction when L. sakei was used as the starter in comparison with other species (González-Fernández et al., 2003; Gençcelep et al., 2007; Latorre-Moratalla et al., 2010b; Baka et al., 2011). L. sakei are usually well adapted to the ecology of meat fermentation and are competitive between the temperatures of 15 and $25^{\circ} \mathrm{C}$, which is the temperature range for sausages manufacture in European Countries (Hugas and Monfort, 1997; Bover-Cid et al., 2001b). In the study carried out by González-Fernández et al. (2003), among all the decarboxylase negative strains tested, L. sakei K29 showed the most efficiency in reducing amine production probably because this strain caused a rapid $\mathrm{pH}$ drop during sausage fermentation. Bover-Cid et al. (2001b) also described that the amino acid decarboxylase negative strain L. sakei CTC494 showed a strong ability to reduce biogenic amine formation in Spanish fermented sausage. However, when this same strain (L. sakei CTC494) was combined with S. carnosus LHT 2102, S. xylosus CTC3037 or S. xylosus CTC3050 an even more effective reduction of amine accumulation was achieved compared with the effect of each strain used alone (Bover-Cid et al., 1999b, 2000c). Similarly, Latorre-Moratalla et al. (2010b) described that the rate of reduction was improved when a mixed starter was used. Thus, after the addition of a single strain of S. equorum, the contents of cadaverine were reduced by $45 \%$ and the single strain of $L$. sakei inoculated in the same product was far more effective, reducing cadaverine by $75 \%$. However, both strains (L. sakei and S. equorum) used together as a mixed starter reduced cadaverine by $89 \%$. In fact, mixed starters may perform better than single starters being able to control the growth of different bacterial groups (Bover-Cid et al., 2000c; Latorre-Moratalla et al., 2010b; Naila et al., 2010).

Commercial starters usually used in industrial manufacture may not be fully adapted to the meat fermentation environment or more specifically to traditional fermenting conditions. Nowadays, for the fermentation of artisanal sausages the addition of the so-called autochthonous starter cultures consisting of selected strains originating from each specific fermented meat product is recommended (Benito et al., 2007; Talon et al., 2007; Casquete et al., 2011). Thus, an autochthonous starter helps to maintain the typical unique characteristics of artisanal products (Talon et al., 2007). This better adaptation and competitiveness of autochthonous starters compared with commercial ones could explain the greater reduction of biogenic amine contents in artisanal meat fermented products.

In this line, commercial mixed starters combining different LAB and staphylococci species (Hernández-Jover et al., 1997b; Ayhan et al., 1999; Gücükoglu and Küplülü, 2010) showed poorer amine reductions than those provided by mixed autochthonous starter cultures (Talon et al., 2008; Latorre-Moratalla et al., 2010b; Casquete et al., 2011). Talon et al. (2008) and Latorre-Moratalla et al. (2010b) evaluated the effect of autochthonous starter cultures without amino decarboxylase activity on biogenic amine 
Table 2 | Different studies on the effect of amine-negative starter cultures on biogenic amine reduction during the manufacture of fermented sausages.

\begin{tabular}{|c|c|c|c|}
\hline Product & Starter culture & $\%$ Of reduction & Reference \\
\hline Fuet & $\begin{array}{l}\text { Micrococcus carnosus + Lactobacillus } \\
\text { plantarum (Texel, France) }\end{array}$ & $25 \%$ of $\mathrm{TI}, 61 \%$ of $\mathrm{CA}$, and $25 \%$ of $\mathrm{PU}$ & Hernández-Jover et al. (1997b) \\
\hline Fuet & $\begin{array}{l}\text { Staphylococcus carnosus LTH } 2102 \\
\text { S. xylosus СТС } 3037 \\
\text { S. xylosus СТС } 3050\end{array}$ & $\begin{array}{l}25 \% \text { of } \mathrm{TY}, 23 \% \text { of } \mathrm{CA} \text {, and } 17 \% \text { of } \mathrm{PU} \\
69 \% \text { of } \mathrm{TY}, 66 \% \text { of } \mathrm{CA} \text {, and no effect on PU } \\
69 \% \text { of } \mathrm{TY}, 17 \% \text { of } \mathrm{CA} \text {, and } 28 \% \text { of } \mathrm{PU}\end{array}$ & Bover-Cid et al. (1999b) \\
\hline Fuet & $\begin{array}{l}\text { L. sakei CTC494 + S. carnosus LTH2102 } \\
\text { L. sakei CTC494+ S. xylosus CTC3037 } \\
\text { L. sakei CTC494+ S. xylosus CTC3050 }\end{array}$ & $\begin{array}{l}90 \% \text { of } \mathrm{TY}, 87 \% \text { of } \mathrm{CA} \text {, and } 37 \% \text { of } \mathrm{PU} \\
87 \% \text { of } \mathrm{TY}, 87 \% \text { of } \mathrm{CA} \text {, and } 37 \% \text { of } \mathrm{PU} \\
90 \% \text { of } \mathrm{TY}, 87 \% \text { of } \mathrm{CA} \text {, and } 37 \% \text { of } \mathrm{PU}\end{array}$ & Bover-Cid et al. (2000c) \\
\hline Fuet & $\begin{array}{l}\text { L. sakei CTC494 (high quality raw } \\
\text { material) } \\
\text { L. sakei CTC494 (poor-quality raw } \\
\text { material) }\end{array}$ & $\begin{array}{l}87 \% \text { of } \mathrm{TY}, 38 \% \text { of } \mathrm{HI}, 41 \% \text { of } \mathrm{CA} \text {, and } 67 \% \\
\text { of PU } \\
39 \% \text { of TY, } 29 \% \text { of } \mathrm{HI}, 14 \% \text { of } \mathrm{CA} \text {, and } 57 \% \\
\text { of PU }\end{array}$ & Bover-Cid et al. (2001b) \\
\hline Salchichón & P. acidilactici MS198 + S. vitulus RS34* & $\begin{array}{l}38 \% \text { of TY, } 74 \% \text { of } \mathrm{HI} \text {, and } 77 \% \text { of } \mathrm{CA} \text {. No } \\
\text { effect on PU } \\
70 \% \text { of TY, } 82 \% \text { of } \mathrm{HI}, 64 \% \text { of } \mathrm{CA} \text {, and } 89 \% \\
\text { of PU } \\
65 \% \text { of } \mathrm{CA} \text {. No effect on } \mathrm{HI}, \mathrm{TY} \text {, and PU } \\
58 \% \text { of } \mathrm{HI}, 71 \% \text { of } \mathrm{CA} \text {, and } 72 \% \text { of PU. No } \\
\text { effect on TY }\end{array}$ & Casquete et al. (2011) \\
\hline Chorizo & $\begin{array}{l}\text { L. sakei K29 } \\
\text { Pediococcus sp. P22 } \\
\text { Pediococcus sp. P208 (Rhodia Food, } \\
\text { France) }\end{array}$ & $\begin{array}{l}98 \% \text { of } \mathrm{TY}, 100 \% \text { of } \mathrm{CA} \text { and } 98 \% \text { of } \mathrm{PU} \\
92 \% \text { of } \mathrm{TY}, 67 \% \text { of } \mathrm{CA} \text {, and } 93 \% \text { of } \mathrm{PU} \\
81 \% \text { of } \mathrm{TY}, 100 \% \text { of } \mathrm{CA} \text {, and } 89 \% \text { of } \mathrm{PU}\end{array}$ & González-Fernández et al. (2003) \\
\hline $\begin{array}{l}\text { French fermented } \\
\text { sausage }\end{array}$ & L. sakei+S. succinus + S. equorum & $87 \%$ of $\mathrm{TY}, 35 \%$ of $\mathrm{CA}$, and $38 \%$ of $\mathrm{PU}$ & Talon et al. (2008) \\
\hline Salami & $\begin{array}{l}\text { L. plantarum VLT } 73+\text { Kokuria varians } \\
\text { MIAL } \\
\text { L. plantarum VLT } 73\end{array}$ & $\begin{array}{l}26 \% \text { of } \mathrm{CA} \text { and } 27 \% \text { of PU. No effect on TY } \\
\text { and } \mathrm{HI} \\
47 \% \text { of } \mathrm{CA} \text {. No effect on TY, HI, and PU }\end{array}$ & Coloretti et al. (2008) \\
\hline $\begin{array}{l}\text { Greek fermented } \\
\text { sausage }\end{array}$ & $\begin{array}{l}\text { L. sakei ( }+0.5 \% \text { of satureja tymbra } \\
\text { extract oil) }\end{array}$ & $62 \%$ of $\mathrm{TY}, 71 \%$ of $\mathrm{HI}$, and $100 \%$ of $\mathrm{PU}$ & Latorre-Moratalla et al. (2010b) \\
\hline \multirow[t]{2}{*}{$\begin{array}{l}\text { Greek fermented } \\
\text { sausage }\end{array}$} & L. sakei 4413 & $13 \%$ of TY and $72 \%$ of $\mathrm{PU}$. No effects on CA & Baka et al. (2011) \\
\hline & $\begin{array}{l}\text { L. sakei } 8426 \\
\text { L. plantarum } 7423 \\
\text { L. curvatus } 8427\end{array}$ & $\begin{array}{l}25 \% \text { of CA. No effect on TY and PU } \\
26 \% \text { of CA. No effect on TY and PU } \\
9 \% \text { of TY and } 29 \% \text { on PU. No effect on CA }\end{array}$ & \\
\hline $\begin{array}{l}\text { Finnish fermented } \\
\text { sausage }\end{array}$ & $\begin{array}{l}\text { P. pentosaceus }+ \text { S. carnosus (Rudolf } \\
\text { Müller and Co, Germany)* }\end{array}$ & $\begin{array}{l}41 \% \text { of TY, } 28 \% \text { of } \mathrm{HI} \text {, and } 86 \% \text { of } \mathrm{CA} \text {. No } \\
\text { effect on PU } \\
79 \% \text { of TY, } 62 \% \text { of } \mathrm{HI} \text {, and } 70 \% \text { of } \mathrm{CA} \text {. No } \\
\text { effect on PU } \\
67 \% \text { of TY, } 77 \% \text { of } \mathrm{HI} \text {. No effect on PU } \\
\text { and CA }\end{array}$ & Maijala et al. (1995) \\
\hline
\end{tabular}


Table 2 | Continued

\begin{tabular}{|c|c|c|c|}
\hline Product & Starter culture & $\%$ Of reduction & Reference \\
\hline Turkish Soudjoucks & $\begin{array}{l}\text { L. sakei+P. pentosaceous }+S . \\
\text { carnosus }+ \text { S. xylosus (Bioback-K, Wiberg, } \\
\text { Germany) }\end{array}$ & $100 \%$ of PU. No effect on TY & Ayhan et al. (1999) \\
\hline Turkish Sucuk & $\begin{array}{l}\text { L. sakei+ S. carnosus } \\
\text { F-SC-111(CHR-HANSEN, Germany) } \\
\text { P. acidilactici+ L. curvatus + S. xylosus } \\
\text { F-LC (CHR-HANSEN, Germany) }\end{array}$ & $\begin{array}{l}88 \% \text { of TY, } 54 \% \text { of } \mathrm{CA} \text {, and } 63 \% \text { of } \mathrm{PU} \text {. No } \\
\text { effect on } \mathrm{HI} \\
86 \% \text { of TY, } 27 \% \text { of } \mathrm{HI}, 62 \% \text { of } \mathrm{CA} \text {, and } 60 \% \\
\text { of PU }\end{array}$ & Gençcelep et al. (2007) \\
\hline \multirow[t]{3}{*}{$\begin{array}{l}\text { Turkish fermented } \\
\text { sausage }\end{array}$} & $\begin{array}{l}\text { L. sakei + S. xylosus B-FM } \\
\text { (CHR-HANSEN, Germany) }\end{array}$ & $54 \%$ of TY and $62 \%$ of $P U$ & Gücükoglu and Küplülü (2010) \\
\hline & $\begin{array}{l}\text { L. plantarum + S. carnosus TD-66 } \\
\text { (CHR-HANSEN, Germany) }\end{array}$ & $52 \%$ of TY and $61 \%$ of $P U$ & \\
\hline & $\begin{array}{l}\text { L. curvatus }+ \text { S. carnosus }+ \text { S. xylosus } \\
\text { RM-10 (CHR-HANSEN, Germany) }\end{array}$ & $55 \%$ of TY and $63 \%$ of $P U$ & \\
\hline \multirow[t]{2}{*}{$\begin{array}{l}\text { Xinese fermented } \\
\text { sausage }\end{array}$} & P. pentosaceus + S. xylosus & $\begin{array}{l}66 \% \text { of } \mathrm{TY}, 49 \% \text { of } \mathrm{CA} \text {, and } 30 \% \text { of PU. No } \\
\text { effect on } \mathrm{HI}\end{array}$ & Lu et al. (2010) \\
\hline & L. farciminis + S. saprophyticus & $\begin{array}{l}83 \% \text { of TY, } 99 \% \text { of } \mathrm{HI}, 99 \% \text { of } \mathrm{CA} \text {, and } 66 \% \\
\text { of PU }\end{array}$ & \\
\hline \multirow[t]{2}{*}{$\begin{array}{l}\text { Thai fermented } \\
\text { sausage }\end{array}$} & L. plantarum BCC9546 (BIOTEC, Thailand) & $94 \%$ of TY, $75 \%$ of $\mathrm{CA}$, and $97 \%$ of $\mathrm{PU}$ & Tosukhowong et al. (2011) \\
\hline & $\begin{array}{l}\text { L. plantarum BCC9546 + L. brevis } \\
\text { BCC26756 (BIOTEC, Thailand) }\end{array}$ & $37 \%$ of $\mathrm{TY}, 75 \%$ of $\mathrm{CA}$, and $99 \%$ of $\mathrm{PU}$ & \\
\hline
\end{tabular}

${ }^{*}$ Starter has been tested in different technological conditions. It is showed the different\% of reduction for each technological condition.

reduction in different artisanal European fermented sausages. The work demonstrated the importance of case-by-case basis strain selection to obtain a good adaptation to the meat fermentation environment and in turn a good biogenic amine prevention.

It has been suggested that the use of bacterial strains with amine oxidase activity might enhance the reduction of biogenic amine accumulation by metabolizing the amines formed during the fermentation. Amine oxidase activity, metabolizing tyramine and/or histamine under in vitro conditions, has been described in microorganisms involved in sausage fermentation, such as specific strains of LAB (L. sakei or L. plantarum) and CNS (S. xylosus; Leuschner and Hammes, 1998; Martuscelli et al., 2000; Fadda et al., 2001; Gardini et al., 2002). However, under real conditions of sausage fermentation, amine-oxidizing microorganisms have shown a limited effect on tyramine and histamine levels, likely due to a low oxygen availability inside the sausage and/or an insufficient number of amine-oxidizing bacteria, e.g., below the minimum $10^{7} \mathrm{cfu} / \mathrm{g}$, required for amine degradation (Leuschner and Hammes, 1998; Gardini et al., 2002).

\section{FACTORS THAT INFLUENCE THE PERFORMANCE OF STARTER CULTURES IN REDUCING BIOGENIC AMINE ACCUMULATION}

The magnitude of reduction of biogenic amine accumulation achieved by a starter culture depends on the factors that determine the presence of endogenous microbiota as well as the competitiveness and implantation of the added starter culture.

It is clearly demonstrated that poor hygienic quality of raw materials and ingredients diminished the protective effect of the amine negative starter culture. Bover-Cid et al. (2001b) reported a significant reduction in the effectiveness of the amino acid decarboxylase negative strain L. sakei CTC494 when sausages were made from raw materials of relatively poor hygienic quality, since high bacterial loads (both of Gram-negative and Gram-positive) increase the number of potentially aminogenic microorganisms and also hamper the implantation and competitiveness of amine negative technological microbiota.

Different processing environment (e.g., pilot plant versus traditional processing plant) and the different type of formulation (e.g., chorizo or fuet) can also significantly influence the performance of the amine negative starter culture. The addition of a mixed starter culture including L. sakei (CTC6469 + CTC6626) and S. xylosus (CTC6013 + CTC6169) with no amino acid decarboxylase activity was successfully used in a fermentation study carried out in pilot plants by Garriga et al. (2005). The starter prevented the accumulation of tyramine, putrescine, and cadaverine by up to $90 \%$ of total amines. However, when the same strains (L. sakei CTC6626 + S. xylosus CTC6013) were inoculated into products produced in a traditional real processing plant, the starter culture showed a weaker effect, only slightly reducing the contents of tyramine and cadaverine, by 19 and 46\%, respectively (Latorre-Moratalla et al., 2010b).

In the literature, several studies have evaluated the effect of factors that influence starter culture on biogenic amine reduction, such as the type and quantity of sugar added (González-Fernández et al., 2003) or the addition of some additives (Bozkurt and Erkmen, 2007; Coloretti et al., 2008). According to the results reported by González-Fernández et al. (2003), when the starter culture, especially L. sakei K29, was used with a sugar concentration of 
0.5 or $1 \%$, the presence of biogenic amines decreased considerably in comparison with the control and low sugar concentration sausage. Bozkurt and Erkmen (2007) described a higher decrease of tyramine, histamine and putrescine contents when a mixture of antimicrobials (nitrite and nitrate), antioxidants, and flavoring and coloring compounds were added with the starter culture mixture of Pediococcus acidilactici, L. plantarum, and S. carnosus.

The influence of processing temperatures on the reducing effect of starter cultures has been fully studied (Maijala et al., 1995; Komprda et al., 2001; Gücükoglu and Küplülü, 2010; Casquete et al., 2011). Gücükoglu and Küplülü (2010) reported that higher ripening temperatures $\left(26^{\circ} \mathrm{C}\right.$ versus $\left.22^{\circ} \mathrm{C}\right)$ potentiated the reduction of putrescine by different starter cultures (L. sakei $+S$. xylosus B-FM, L. plantarum + S. carnosus TD66, and L. curvatus + S. carnosus + S. xylosus RM-10) in experimental Turkish fermented sausages. However, the fermentation temperatures did not have any significant effect on tyramine reduction. Similarly, Casquete et al. (2011) described an influence of temperatures on

\section{REFERENCES}

Ayhan, K., Kolsarici, N., and Özkan, G. A. (1999). The effects a starter culture on the formation of biogenic amines in Turkish soudjoucks. Meat Sci. 53, 183-188.

Aymerich, T., Martín, B., Garriga, M., Vidal-Carou, M. C., Bover-Cid, S., and Hugas, M. (2006). Safety properties and molecular strain typing of lactic acid bacteria from slightly fermented sausages. J. Appl. Microbiol. $100,40-49$.

Baka, A. M., Papavergou, E. J., Pragalaki, T., Bloukas, J. G., and Kotzekidou, P. (2011). Effect of selected autochthonous starter cultures on processing and quality characteristics of Greek fermented sausages. Food Sci. Technol. 44, 54-61.

Bauer, F., Seuss, I., Paulsen, P., and Vali, S. (1994). "The formation of biogenic amines in meat and meat products," in Proceedings of the 40th International Congress Meat Science and Technology (ICoMST), The Hague, S-V25.

Benito, M. J., Martín, A., Aranda, E., Pérez-Nevado, F., Ruiz-Moyano, S., and Córdoba, M. (2007). Characterization and selection of autochthonous lactic acid bacteria isolated from traditional Iberian dry-fermented salchichón and chorizo sausages. J. Food Sci. 72, 193-201.

Bover-Cid, S., and Holzapfel, W. (1999). Improved screening procedure for biogenic amine production by lactic acid bacteria. Int. J. Food Microbiol. $53,33-41$.

Bover-Cid, S., Hugas, M., IzquierdoPulido, M., and Vidal-Carou, M. C. (2001a). Amino acid-decarboxylase activity of bacteria isolated from fermented pork sausages. Int. J. Food Microbiol. 66, 185-189.

Bover-Cid, S., Izquierdo-Pulido, M., and Vidal-Carou, M. C. (2001b). Effectiveness of a Lactobacillus sakei starter culture in the reduction of biogenic amines accumulation as a function of the raw material quality. J. Food Prot. 64, 367-373.

Bover-Cid, S., Izquierdo-Pulido, M., and Vidal-Carou, M. C. (2000a). Influence of hygienic quality of raw materials on biogenic amine production during ripening and storage of dry fermented sausages. J. Food Prot. 63, 1544-1550.

Bover-Cid, S., Hugas, M., IzquierdoPulido, M., and Vidal-Carou, M. C. (2000b). Reduction of biogenic amine formation using a negative amino acid-decarboxylase starter culture for fermentation of fuet sausages. J. Food Prot. 63, 237-243.

Bover-Cid, S., Izquierdo-Pulido, M., and Vidal-Carou, M. C. (2000c). Mixed starter cultures to control biogenic amine production in dry fermented sausages. J. Food Prot. 63, 1556-1562.

Bover-Cid, S., Schoppen, S., IzquierdoPulido, M., and Vidal-Carou, M. C. (1999a). Relationship between biogenic amine contents and the size of dry fermented sausages. Meat Sci. 51, 305-311. and Vidal-Carou, M. C. (1999b). Effect of proteolytic starter cultures of Staphylococcus spp. on biogenic amine formation during the ripening of dry fermented sausages. Int. J. Food Microbiol. 46, 95-104.

Bozkurt, H., and Erkmen, O. (2002). Effects of starter cultures and additives on the quality of Turkish
Bover-Cid, S., Izquierdo-Pulido, M.,

the development and activity of autochthonous starter cultures consisting of $P$. acidilactici MS200 + S. vitulus RS34 and $P$. acidilactici MS198 + S. vitulus RS34. In this case, higher fermentation temperature $\left(12^{\circ} \mathrm{C}\right.$ versus $\left.7^{\circ} \mathrm{C}\right)$ also obtained the highest reduction of amines, probably due to a better adaptation of the starters to the meat fermentation environment.

In conclusion, the absence of decarboxylase activity should be a criterion for the selection of strains intended for use as starter cultures to obtain fermented sausages free of biogenic amines. Mixed starter cultures consisting of amine negative strains of LAB and CNS species, well adapted to the meat fermentation environment, seem the best alternative. Moreover, the use of autochthonous strains is presented as a promising control measure especially for the manufacture of traditional fermented sausages. High quality raw materials and optimal technological conditions are crucial factors to ensure a proper performance of starter cultures for the reduction of biogenic amine accumulation in fermented sausages.

style sausage (Sucuk). Meat Sci. 61, 149-156.

Bozkurt, H., and Erkmen, O. (2004). Effects of temperature, humidity and additives on the formation of biogenic amines in Sucuk during ripening and storage periods. Food Sci. Technol. Int. 10, 21-28.

Bozkurt, H., and Erkmen, O. (2007). Effects of some commercial additives on the quality of Sucuk (Turkish dry-fermented sausage). Food Chem. 101, 1465-1473.

Brink, B. T., Damink, C., Joosten, H., and Huis In't Veld, J. (1990). Occurrence and formation of biologically active amines in foods. Int. J. Food Microbiol. 11, 73-84.

Buckenhüskes, H. (1993). Selection criteria for lactic acid bacteria to be used as a starter cultures for various food commodities. FEMS Microbiol. Rev. 12, 253-272.

Buncic, S., Paunovic, L., Radisic, D., Vojinovic, G., Smiljanic, D., and Baltic, M. (1993). Effects of gluconodeltalactone and Lactobacillus plantarum on the production of histamine and tyramine in fermented sausages. Int. J. Food Microbiol. 17, 303-309.

Casquete, R., Benito, M. J., Martín, A., Ruiz-Moyano, S., Hernández, A., and Córdoba, M. G. (2011). Effect of autochthonous starter cultures in the production of "salchichón", a traditional Iberian dry-fermented sausage, with different ripening processes. Food Sci. Technol. 44, 1562-1571.

Coïsson, J. D., Cerutti, C., Travaglia, F., and Arlorio, M. (2004). Production of biogenic amines in "Salamini italiani alla cacciatora PDO”. Meat Sci. 67, 343-349.
Coloretti, F., Chiavari, C., Armaforte, E., Carri, S., and Castagnetti, B. (2008). Combined use of starter cultures and preservatives to control production of biogenic amines and improve sensorial profile in lowacid salami. J. Agric. Food Chem. 56, 11238-11244.

Durlu-Özkaya, F., Ayhan, K., and Vural, N. (2001). Biogenic amines produced by Enterobacteriaceae isolated from meat products. Meat Sci. 58, 163-166.

Eerola, H. S., Roig-Sagués, A. X., and Hirvi, T. K. (1998). Biogenic amines in Finnish dry sausages. J. Food Saf. 18,127-138.

EFSA Panel on Biological Hazards (BIOHAZ). (2011). Scientific opinion on risk based control of biogenic amine formation in fermented foods. EFSA J. 9, 2393.

Ekici, K., Sekeroglu, R., Sancak, Y. C., and Noyan, T. (2004). Note of histamine levels in Turkish style fermented sausage. Meat Sci. 68, 123-125.

Erkmen, O., and Bozkurt, H. (2004). Quality characteristics of retailed Sucuk (Turkish dry-fermented sausage). Food Technol. Biotechnol. 42, 63-69.

Fadda, S., Vignolo, G., and Oliver, G. (2001). Tyramine degradation and tyramine/histamine production by lactic acid bacteria and Kocuria strains. Biotechnol. Lett. 23, 24.

Gardini, F., Martuscelli, M., Crudele, M. A., Paparella, A., and Suzzi, G. (2002). Use of Staphylococcus xylosus as a starter culture in dried sausages: effect on the biogenic amine content. Meat Sci. 61, 275-283. 
Garriga, M., Marcos, B., Martín, B., Veciana-Nogués, M. T., Bover-Cid, S., Hugas, S., and Aymerich, T. (2005). Starter cultures and high pressure processing to improve the hygiene and safety of slightly fermented sausages. J. Food Prot. 68, 2341-2348.

Gençcelep, H., Kaban, G., and Kaya, M. (2007). Effect of starter cultures and nitrite levels on formation of biogenic amines in sucuk. Meat Sci. 77, 424-430.

González-Fernández, C., Santos, E., Jaime, I., and Rovira, J. (2003). Influence of starter cultures and sugar concentrations of biogenic amine contents in chorizo dry sausage. Food Microbiol. 20, 275-284.

Gücükoglu, A., and Küplülü, Ö. (2010). The effect of different starter cultures and ripening temperatures on formation of biogenic amine in Turkish fermented sausages. Eur. Food Res. Technol. 230, 875-884.

Halász, A., Baráth, A., Simon-Sakardi, L., and Holzapfel, W. (1994). Biogenic amines and their production by microorganisms in food. Trends Food Sci. Technol. 5, 42-49.

Hernández-Jover, T., Izquierdo-Pulido, M., Veciana-Nogués, M. T., MarinéFont, A., and Vidal-Carou, M. C. (1997a). Biogenic amine and polyamine contents in meat and meat products. J. Agric. Food Chem. 45, 2098-2102.

Hernández-Jover, T., IzquierdoPulido, M., Veciana-Nogués, M. T., Mariné-Font, A., and VidalCarou, M. C. (1997b). Effect of starter cultures on biogenic amine formation during fermented sausage production. J. Food Prot. 60, 825-830.

Hugas, M., and Monfort, J. M. (1997). Bacterial starter cultures for meat fermention. Food Chem. 59, 547554.

Komprda, T., Neznalovà, J., Standara, S., and Bover-Cid, S. (2001). Effect of starter culture and storage temperature on the content of biogenic amines in dry fermented sausages Polican. Meat Sci. 59, 267-276.

Komprda, T., Smela, D., Pechova, P., Kalhotka, L., Stencl, J., and Klejdus, B. (2004). Effect of starter culture, spice mix and storage time and temperature on biogenic amine content of dry fermented sausages. Meat Sci. 67, 607-616.

Landete, J. M., de las Rivas, B., Marcobal, A., and Muñoz, R. (2007). Molecular methods for the detection of biogenic amine-producing bacteria on foods. Int. J. Food Microbiol. 117, 258-269.

Latorre-Moratalla, M. L., Bover-Cid, S., Bosch-Fusté, J., and Vidal-Carou, M. C. (2012). Influence of technological conditions of sausage fermentation on the aminogenic activity of L. curvatus CTC273. Food Microbiol. 29, 43-48.

Latorre-Moratalla, M. L., Bover-Cid, S., Talon, R., Garriga, M., Aymerich, T., Zanardi, E., Ianieri, A., Fraqueza, M. J., Elias, M., Drosinos, E. H., Lauková, A., and Vidal-Carou, M. C. (2010a). Distribution of aminogenic activity among potential autochthonous starter cultures. J. Food Prot. 73, 524-525.

Latorre-Moratalla, M. L., Bover-Cid, S., Talon, R., Garriga, M., Aymerich, T., Zanardi, E., Ianieri, A., Fraqueza, M. J., Elias, M., Drosinos, E. H., Lauková, A., and Vidal-Carou, M. C. (2010b). Strategies to reduce biogenic amine accumulation in traditional sausage manufacturing. Food Sci. Technol. 43, 20-25.

Leuschner, R. G. K., and Hammes, W. P. (1998). Tyramine degradation by micrococci during ripening of fermented sausage. Meat Sci. 49, 189-196.

Linares, D. M., Martín, M. C., Ladero, V., Âlvarez, M. A., and Fernández, M. (2011). Biogenic amines in dairy products. Crit. Rev. Food Sci. Nutr. 51, 691-703.

Lonvaud-Funel, A. (2001). Biogenic amines in wines: role of lactic acid bacteria. FEMS Microbiol. Lett. 199, 9-13.

Lu, S., Xu, X., Zhou, G., Zhu, Z., Meng, Y., and Sun, Y. (2010). Effect of starter cultures on microbial ecosystem and biogenic amines in fermented sausage. Food Control 21, 444-449.

Maijala, R., and Eerola, S. (1993). Contaminant lactic acid bacteria of dry sausages. Meat Sci. 35, 387-395.

Maijala, R., Eerola, S., Lievonen, S., Hill, P., and Hirvi, T. (1995). Formation of biogenic amines during ripening of dry sausages as affected by starter culture and thawing time of raw materials. J. Food Sci. 69 , 1187-1190.

Marcobal, A., de las Rivas, B., and Muñoz, R. (2006). Methods for the detection of bacteria producing biogenic amines on foods: a survey. $J$. Verbr. Lebensm. 1, 187-196.

Mariné-Font, A., Vidal-Carou, M. C., Izquierdo-Pulido, M.,
Veciana-Nogués, M. T., and Hernández-Jover, T. (1995). Les amines biogenes dans les aliments: leur signification, leur analyse. Ann. Falsif. Expert. Chim. Tox. 88, 119-140.

Martín, B., Garriga, M., Hugas, M., Bover-Cid, S., VecianaNogués, M. T., and Aymerich, T. (2006). Molecular, technological and safety characterization of Gram-positive catalase-positive cocci from slightly fermented sausages. Int. J. Food Microbiol. 107, 148-158.

Martuscelli, M., Crudele, M., Gardini, F., and Suzzi, G. (2000). Biogenic amine formation and oxidation by Staphylococcus xylosus from artisanal fermented sausages. J. Appl. Microbiol. 31, 228-232.

Masson, F., Talon, R., and Montel, M. (1996). Histamine and tyramine production by bacteria from meat products. Int. J. Food Microbiol. 32, 199-207.

Montel, M., Masson, F., and Talon, R. (1999). Comparison of biogenic amine content in traditional and industrial French dry sausages. Sci. Aliments 19, 247-254

Naila, A., Flint, S., Fletcher, G., Bremer, P., and Meerdink, G. (2010). Control of biogenic amines in food-existing and emerging approaches. J. Food Sci. 75, 139-150.

Parente, E., Martuscelli, M., Gardini, F., Grieco, S., Crudele, M. A., and Suzzi, G. (2001). Evolution of microbial populations and biogenic amine production in dry sausages produced in southern Italy. J. Appl. Microbiol. 90, 882-891.

Paulsen, P., and Bauer, F. (1997). Biogenic amines in fermented sausages. II. Factors influencing the formation of biogenic amines in fermented sausages. Fleischwirtschaft 77, 32-34.

Rice, S., and Koehler, P. (1976). Tyrosine and histidine decarboxylase activities of Pediococcus cerevisiae and Lactobacillus species and the production of tyramine in fermented sausages. $J$. Milk Food Technol. 39, 353-358.

Riebroy, S., Benjakul, S., Visessanguan, W., Kijrongrojana, K., and Tanaka, M. (2004). Some characteristics of commercial Som-fug produced in Thailand. Food Chem. 88, 527-535.

Roig-Sagués, A., Hernández-Herrero, M., López-Sabater, E., RodríguezJerez, J., and Mora-Ventura, M. (1996). Histidine decarboxylase activity of bacteria isolated from raw and ripened salchichón, a Spanish cured sausage. J. Food Protec. 59, 516-520.
Roig-Sagués, A. X., Hernández-Herrero, M., Rodríguez-Jerez, J. J., LópezSabater, E. I., and Mora-Ventura, M. T. (1997). Occurrence of tyramine producing microorganisms in "salchichón" and tyramine production in sausages inoculated with a tyramine producing strain of Lactobacillus brevis. J. Food Saf. 17, 13-22.

Ruiz-Capillas, C., and JiménezColmenero, F. (2004). Biogenic amine content in Spanish retail market meat products treated with protective atmosphere and high pressure. Eur. Food Res. Technol. 218, 237-241.

Shalaby, A. R. (1993). Survey in biogenic amines in Egyptian foods: sausage. J. Sci. Food Agric. 62, 291-293.

Silla-Santos, H. (1998). Amino acid decarboxylase capability of microorganisms isolated in Spanish fermented meat products. Int. J. Food Microbiol. 39, 227-230.

Spano, G., Russo, P., Lonvaud-Funel, A., Lucas, P., Alexandre, H., Grandvalet, C., Coton, E., Coton, M., Barnavon, L., Bach, B., Rattray, F., Bunte, A., Magni, C., Ladero, V., Alvarez, M., Fernández, M., Lopez, P., de Palencia P. F., Corbi, A., Trip, H., and Lolkema, J. S. (2010). Biogenic amine in fermented foods. Eur. J. Clin. Nutr. 64, 95-100.

Straub, B. W., Kicherer, M., Schilcher, S. M., and Hammes, W. P. (1995). The formation of biogenic amines by fermentation organisms. Z. Lebens. Unters. Forsch. 201, 79-82.

Straub, B. W., Tichaczek, P. S., Kicherer, M., Schilcher, S. M., and Hammes, W. P. (1994). Formation of tyramine by Lactobacillus curvatus lth-972. Z. Lebens. Unters. Forsch. 199, 9-12.

Suzzi, G., and Gardini, F. (2003). Biogenic amines in dry fermented sausages: a review. Int. J. Food Microbiol. 88, 41-54.

Talon, R., and Leroy, S. (2011). Diversity and safety hazards of bacteria involved in meat fermentation. Meat Sci. 89, 303-309.

Talon, R., Leroy, S., and Lebert, I. (2007). Microbial ecosystems of traditional fermented meat products: the importance of indigenous starters. Meat Sci. 77, 55-62.

Talon, R., Leroy, S., Lebert, I., Giammarinaro, P., Chacornac, J. P., Latorre-Moratalla, M. L., VidalCarou, M. C., Zanardi, E., Conter M., and Lebecque, A. (2008). Safety improvement and preservation of typical sensory qualities of traditional dry fermented sausages using autochthonous starter cultures. Int. J. Food Microbiol. 126, 227-234. 
Tosukhowong, A., Visessanguan, W, Pumpuang, L., Tepkasikul, P., Panya, A., and Valyasevi, R. (2011). Biogenic amines formation in Nham, a Thai fermented sausage and the reduction by commercial starter culture, Lactobacillus plantarum BCC 9546 . Food Chem. 129, 846-853.

Vidal-Carou, M. C., Izquierdo, M. L., Martín, M. C., and Mariné, A. (1990). Histamina y tiramina en derivados cárnicos. Rev. Agroquim. Tecnol. Aliment. 30, 102-108.
Vidal-Carou, M. C., Latorre-Moratalla, M. L., Veciana-Nogués, M. T., and Bover-Cid, S. (2007). "Biogenic amines: risks and control," in Handbook of Fermented Meat and Poultry, eds F. Todrà, Y. H. Hui, I. Astiasarán, Wai-Kit Nip, J. G. Sebranek, E. T. F. Silveira, L. H. Stahnke, and R. Talon (Oxford: Blackwell Publishing), 455-468.

Conflict of Interest Statement: The authors declare that the research was conducted in the absence of any commercial or financial relationships that could be construed as a potential conflict of interest.

Received: 07 March 2012; paper pending published: 11 April 2012; accepted: 16 April 2012; published online: 07 May 2012.

Citation: Latorre-Moratalla ML, BoverCid S, Veciana-Nogués MT and VidalCarou MC (2012) Control of biogenic amines in fermented sausages: role of starter cultures. Front. Microbio. 3:169. doi: 10.3389/fmicb.2012.00169

This article was submitted to Frontiers in Food Microbiology, a specialty of Frontiers in Microbiology.

Copyright () 2012 Latorre-Moratalla, Bover-Cid, Veciana-Nogués and VidalCarou. This is an open-access article distributed under the terms of the Creative Commons Attribution Non Commercial License, which permits non-commercial use, distribution, and reproduction in other forums, provided the original authors and source are credited. 